\title{
Forskarhandledning på frammarsch
}

\author{
Jan Stockfors
}

Tidskriften Högre utbildning föddes ur ett behov av väl underbyggd kunskap om undervisning och lärande i svensk högre utbildning. Genom framväxten av högskolepedagogisk utbildning vid våra svenska lärosäten blev värdet av erfarenhetsutbyte och vetenskaplig kunskap om utbildning och lärande i den svenska högskolan uppenbart för allt fler. I kölvattnet av det växande intresset för högskolepedagogik ökar nu också intresset för väl underbyggd kunskap om forskarutbildning och pedagogiken kring den speciella utbildningssituation som det innebär att vara doktorand respektive forskarhandledare. I forskarhandledningen ställs många såväl pedagogiska som etiska frågeställningar på sin spets. Den långsiktiga relation och den många gånger krävande process som forskarutbilning och forskarhandledning innebär ställer stora krav på både doktorander och handledare. Det är därför glädjande att hela tre artiklar i det här numret av Högre utbildning tar upp frågor som rör just forskarutbildning och handledning.

Ett annat högaktuellt ämne är kritiskt tänkande och den roll som universitet och högskolor har för att förse vårt samhälle med kritiskt reflekterande medborgare. För att kunna möta de komplexa problem och frågeställningar mänskliga samhällen står inför på såväl lokal som global nivå behöver våra studenter kunna kombinera ett kritiskt förhållningssätt till omvärlden med en förmåga till kritisk självreflektion. Studenter som lämnar universitet och högskolor behöver också, med stöd i en god självkänsla, ha styrkan och förmågan att uttrycka sin kritik och agera kritiskt. I det här numret har vi förmånen att presentera två artiklar som på olika sätt belyser vikten av kritiskt tänkande och den breda innebörd som detta nyckelbegrepp för högre utbildning har.

\section{Bidrag i Högre utbildning nr 22017}

I sin reflektionsartikel Kritisk själureflektion $i$ komplexa frägor: Att hjälpa studenterna att ta makten över sitt tänkande vänder Maria Wolrath Söderberg den kritiska blicken inåt och undersöker mekanismer som hindrar oss från att tänka kritiskt och handla i linje med de kunskaper och värderingar vi själva faktiskt har. Med utgångspunkt i ett personligt exempel problematiserar hon tre faktorer som försvårar vårt kritiska tänkande i komplexa frågeställningar, till exempel frågor som rör hållbar utveckling. De tre faktorer Wolrath Söderberg tar upp är: vår bristande förmåga att hantera komplexa frågeställningar; det som kallas "Backfire"-effekten och gapet mellan kunskap och handling. En väg framåt och ett sätt att i pedagogiska sammanhang arbeta med oss själva och synliggöra hur vi tänker hittar hon i den aristoteliska toposläran som på senare år har aktualiserats som ett redskap för kritisk självreflektion.

Ett annat brett anslag till kritiskt tänkande har Magdalena Bexell och Sara Kalm i artikeln Kritiskt tänkande i forskarutbildningen - handledares röster om ett betydelsefullt examensmål. Där undersöker de hur forskarhandledare i statsvetenskap ser på vad kritiskt tänkande innebär och

\footnotetext{
* Författarkontakt: Jan Stockfors, Jan.Stockfors@slu.se

Artiklar och reflektioner är kollegialt granskade. Övriga bidragstyper granskas av redaktionen. Se www.hogreutbildning.se ISSN 2000-7558

(C)2017 Jan Stockfors. This is an Open Access article distributed under the terms of the Creative Commons Attribution-NonCommercial 4.0 International License (https://creativecommons.org/licenses/by-nc/4.0/), allowing third parties to share their work (copy, distribute, transmit) and to adapt it, under the condition that the authors are given credit, that the work is not used for commercial purposes, and that in the event of reuse or distribution, the terms of this license are made clear.

Citation: Jan Stockfors (2017) «Forskarhandledning på frammarsch». Högre utbildning 7(2), 91-93. http://dx.doi.org/10.23865/hu.v7.1137
} 


\section{J. Stockfors}

vilka förutsättningar som finns för utvecklingen av doktoranders kritiska tänkande under forskarutbildningen. Bland handledarna i statsvetenskap finns en samsyn kring mycket av vad som är centralt i begreppet kritiskt tänkande, men det finns också tydliga skillnader. Intressant är att dessa skillnader i Bexells och Kalms studie inte verkar kopplade till underdisciplin inom statsvetenskapen utan snarare till handledares vetenskapsteoretiska orientering. Gemensamt för alla de intervjuade handledarna är också en upplevelse av att det kritiska tänkandet i forskarutbildningen på olika sätt är hotat.

Forskarutbildningen i Sverige har genomgått stora förändringar bland annat genom Bolognareformen, genom förändrade finansieringsstrukturer och genom ett ökat tryck på mätbara produktionsmått. I dessa förändringar finns sannolikt rötterna till några av de hot mot det kritiska tänkandet handledare i Bexells och Kalms studie identifierade. Samma förändringar kan också vara en av grunderna till de dilemman forskarhandledare inom utbildningsvetenskapen upplever och som Tünde Puskás och Fredrik Jeppsson problematiserar i sin reflektion Om forskarhandledningens mål, samförfattarskap och meritering: Några dilemman inom det utbildningsvetenskapliga fältet. Puskás och Jeppsson konstaterar att det har skett en förändring i publiceringsmönster inom utbildningsvetenskapen. Doktorsavhandlingar som tidigare framförallt publicerats i form av monografier på svenska ersätts i allt högre grad av sammanläggningsavhandlingar på engelska. Den här tendensen blir problematisk om man ser till grunderna för att etablera forskningsfältet Utbildningsvetenskap, nämligen att forskningen skulle vara praktiknära och bedrivas i nära samarbete med lärarutbildningarna och skolan. Puskás och Jeppsson grundar sin reflektion i intervjuer med fyra forskarhandledare. Ett av de dilemman som blir tydliga i reflektionsartikeln är skärningen eller kollisionen mellan två perspektiv på forskarutbildning. Forskarutbildning som en sorts hantverksutbildning för en framtida forskarkarriär eller forskarutbildning som en intellektuell bildningsresa präglad av en djupare vetenskaplig förståelse.

I den tredje artikeln som tar upp forskarhandledning, Improvisational approaches to supervision dialogue, tar Sven Bjerstedt upp improvisationen som en viktig komponent i handledarsamtalet. Bjerstedt lyfter i sin artikel fram paralleller till samtalet mellan doktorand och handledare i jazzmusikers improvisationer. Här finns behov av såväl förberedelser och erfarenhet som lyhördhet och vilja att ta avstamp i något nytt och okänt. En viktig slutsats i Bjerstedts artikel är att de lokala strukturer och ramverk inom vilka forskarutbildning genomförs måste ge utrymme för improvisation.

Med de tre återstående bidragen i detta nummer lämnar vi forskarutbildningen och återvänder till utbildning på grund och avancerad nivå. Gunlög Josefsson och Katarina Lundin undersöker i artikeln Tröskelbegrepp inom grammatiken var svårigheterna med grammatik ligger. De identifierar och exemplifierar på ett tydligt sätt tre tröskelbegrepp inom grammatikens område: skillnaden mellan betydelse, form och funktion; den hierarkiska principen och avgränsningen av fraser och satser. Josefsson och Lundin diskuterar i artikelns avslutande avsnitt ett antal didaktiska implikationer och förslag på hur lärare kan underlätta studenternas lärande så att de tar sig över dessa trösklar. De resonerar kring olika möjligheter men ser samtidigt risker att lärare öppnar vägar för studenterna att undvika trösklarna istället för att ta sig över dem. Om så blir fallet har vi förvisso ökat genomströmningen men utan att studenterna har utvecklat de kunskaper som de förväntas ha med sig efter kursen.

I avdelningen Goda exempel har vi i det här numret ett högaktuellt bidrag. Det är Hedda Söderlundh, Therese Lind och Anders Nordström som under rubriken Hur fär man en 
högskolepedagogisk satsning att leva vidare? Nägra reflektioner kring ämnesintegrering av akademiskt skrivande på Polisutbildningen tar upp såväl akademiskt skrivande inom yrkesprogram som problematiken att få tidsbegränsade insatser att ge bestående effekter. Söderlundh, Lind och Nordström beskriver hur Utvecklingsenheten för högskolepedagogik och bildning, Biblioteket samt Studieverkstan vid Södertörns högskola, i det presenterade fallet, samarbetat med Polisutbildningen. Syftet har varit att redan tidigt i utbildningen introducera akademiskt skrivande. Inledningsvis fick programmet mycket stöd från de inblandade enheterna, men efter en samarbetsperiod på tre terminer genomförs nu utvecklingen av studenternas skrivande integrerat i en kurs av de ordinarie lärarna. Författarna delar avslutningsvis med sig av ett antal punkter som de ser har varit avgörande för satsningens framgång.

Slutligen reflekterar Andreas Håkansson över den i högskolepedagogiska sammanhang eviga frågan om förläsningens roll i undervisningen och ställer den retoriska frågan Vad ska vi med föreläsningar till? Föreläsningen som undervisningsform blir lätt den symboliska måltavlan när föråldrad och passiviserande undervisning som driver studenterna till ytinlärning ska kritiseras. Håkansson vill ifrågasätta de breda angreppen på föreläsningsformen och lyfter fram tre områden där föreläsningen kan ha tydliga fördelar: nytolkningar och omformuleringar; grundläggande struktur och exemplifiering av akademisk reflektion. Håkanssons reflektion pekar mot att det kanske är viktigare att undersöka skillnader mellan bra och dåliga föreläsningar än att ifrågasätta hela denna mångfacetterade undervisningsform som om den alltid var en och densamma. 